evolution and 100 replications for maximum likelihood. Shape parameters for the gamma distribution were estimated from minimum length trees ${ }^{26}$ and were 0.32 (mtDNA), 0.59 (vWF) and 0.52 (A2AB).

Divergence times. $12 \mathrm{~S}$ rRNA transversions accumulated linearly as far back as the eutherian-metatherian split ${ }^{24}$. Nine independent cladogenic events were selected based on 12S rRNA sequence availability and paleostratigraphic data $^{10,24,30}$ (for example, Rattus to Mus (14 Myr); Sus to Tayassu (45 Myr); ruminants to Cetacea (60 Myr); Erinaceus to Metatheria (130 Myr)). Relative rates were calculated in reference to xenarthrans. Tamura-Nei transversion distances (transversions only) were adjusted for relative rate differences ${ }^{30}$ against the xenarthran standard. Rate-adjusted estimates of sequence divergence were regressed against paleostratigraphic divergence estimates for each of the nine calibration points (origin forced through zero; $r^{2}=0.97$; $P=0.0000002$ ). The resulting equation (divergence time (in Myr) $=$ sequence divergence/0.00063) was used to estimate interordinal divergence times after making similar adjustments for relative rates. Additional details will be presented elsewhere (M.S., manuscript in preparation).

Received 23 December 1996; accepted 18 April 1997.

1. Novacek, M. J. Mammalian phylogeny: shaking the tree. Nature 356, 121-125 (1992).

2. Huxley, T. H. On the application of the laws of evolution to the arrangement of the Vertebrata, and more particularly to the Mammalia. Proc. R. Soc. Lond. 43, 649-662 (1880).

3. Matthew, W. D. The Carnivora and Insectivora of the Bridger Basin, Middle Eocene. Mem. Am. Mus. Nat. Hist. 9, 291-567 (1909).

4. MacPhee, R. D. E. \& Novacek, M. J. in Mammal Phylogeny Vol. 2, Placentals (eds Szalay, F. S., Novacek, M. J. \& McKenna, M. C.) 13-31 (Springer, New York, 1993),

Carroll, R. L. Vertebrate Paleontology and Evolution (Freeman, New York, 1988).

6. Gheerbrant, E., Sudre, J. \& Cappetta, H. A Palaeocene proboscidean from Morocco. Nature 383, 68 70 (1996).

7. Lavergne, A., Douzery, E., Stichler, T., Catzeflis, F. M. \& Springer, M. S. Interordinal mammalian relationships: evidence for paenungulate monophyly is provided by complete mitochondrial $12 \mathrm{~S}$ rRNA sequences. Mol. Phyl. Evol. 6, 245-258 (1996).

8. Madsen, O., Deen, P. M. T., Pesole, G., Saccone, C. \& de Jong, W. W. Molecular evolution of mammalian aquaporin-2: further evidence that elephant shrew and aardvark join the paenungulate clade. Mol. Biol. Evol. 14, 363-371 (1997).

9. Porter, C. A., Goodman, M. \& Stanhope, M. J. Evidence on mammalian phylogeny from sequences of exon 28 of the von Willebrand factor gene. Mol. Phys. Evol. 5, 89-101 (1996).

10. Stanhope, M. J. et al. Mammalian evolution and the interphotoreceptor retinoid binding protein (IRBP) gene: convincing evidence for several superordinal clades. J. Mol. Evol. 43, 83-92 (1996)

11. Cope, E. D. The condylarthra. Am. Nat. 18, 790-805, 892-906 (1884).

12. Fischer, M. S. \& Tassy, P. in Mammal Phylogeny Vol. 2, Placentals (eds Szalay, F. S., Novacek, M. J. \& McKenna, M. C.) 217-234 (Springer, New York, 1993).

13. de Jong, W. W., Zweers, A. \& Goodman, M. Relationship of aardvark to elephants, hyraxes and sea cows from $\alpha$-crystallin sequences. Nature 292, 538-540 (1981)

14. de Jong, W. W., Leunissen, J. A. M. \& Wistow, G. J. in Mammal Phylogeny Vol. 2, Placentals (eds Szalay F. S., Novacek, M. J. \& McKenna, M. C.) 5-12 (Springer, New York, 1993).

15. Faith, D. P. Cladistic permutation tests for monophyly and nonmonophyly. Syst. Zool. 40, 366-375 (1991).

16. Kishino, H. \& Hasegawa, M. Evaluation of the maximum likelihood estimate of the evolutionary tree topologies from DNA sequence data, and the branching order in Hominoidea. J. Mol. Evol. 29, 170 179 (1989).

17. Glover, T. D. Aspects of sperm production in some east African mammals. J. Reprod. Fertil. 35, 45-53 (1973).

18. Hartenberger, J. L. Hypothese paleontologique sur l'origine des Macroscelidea (Mammalia). C.R. Acad. Sci. 302, 247-249 (1986).

19. Novacek, M. in Macromolecular Sequences in Systematic and Evolutionary Biology (ed. Goodman, M.) 3-41 (Plenum, New York, 1982).

20. Sibley, C. G. \& Ahlquist, J. E. Reconstructing bird phylogeny by comparing DNAs. Sci. Am. 254, 82-92 (1986).

21. Hedges, S. B., Parker, P. H., Sibley, C. G. \& Kumar, S. Continental breakup and the ordinal diversification of birds and mammals. Nature 381, 226-229 (1996).

22. Springer, M. S., Hollar, L. J. \& Burk, A. Compensatory substitutions and the evolution of the mitochondrial 12 S rRNA gene in mammals. Mol. Biol. Evol. 12, 1138-1150 (1995).

23. Thompson, J. D., Higgins, G. D. \& Gibson, T. J. CLUSTAL W: improving the sensitivity of progressive multiple sequence alignment through sequence weighting, position-specific gap penalties and weight matrix choice. Nucleic Acids Res. 22, 4673-4680 (1994).

24. Springer, M. S. \& Douzery, D. Secondary structure and patterns of evolution among mammalian mitochondrial 12 S rRNA molecules. J. Mol. Evol. 43, 357-373 (1996).

25. De Rijk, P., Van de Peer, Y., Chapelle, S. \& De Wachter, R. Nucleic Acids Res. 22, 3495-3501 (1994).

26. Swofford, D. L., Olsen, G. J., Waddell, P. J. \& Hillis, D. M. in Molecular Systematics (eds Hillis, D. M. Moritz, C. \& Mable, B. K.) 407-514 (Sinauer, Sunderland, MA, 1996).

27. Tamura, K. \& Nei, M. Estimation of the number of nucleotide substitutions in the control region of mitochondrial DNA in humans and chimpanzees. Mol. Biol. Evol. 10, 512-526 (1993).

28. Lockhart, P. J., Steel, M. A., Hendy, M. D. \& Penny, D. Recovering evolutionary trees under a more realistic model of sequence evolution. Mol. Biol. Evol. 11, 605-612 (1994).

29. Hasegawa, M., Kishino, H. \& Yano, T. Dating of the human-ape splitting by a molecular clock of mitochondrial DNA. J. Mol. Evol. 21, 160-174 (1985).

30. Arnason, U., Gullberg, A., Janke, A. \& Xu, X. Pattern and timing of evolutionary divergences among hominoids based on analyses of complete mtDNAs. J. Mol. Evol. 43, 650-661 (1996).

Acknowledgements. This work was supported by the Alfred P. Sloan Foundation, the European Commission, the NSF, the Nuffield Foundation and the Royal Society. We thank D. Willemsen for technical assistance, D. Swofford for permission to use PAUP 4.0d52-54, and F. Catzeflis, E. Harley, J. Kirsch, G. Olbricht, J. Wensing and the Noorder Zoo for tissue samples.

Correspondence and requests for materials should be addressed to M.S.S. (e-mail: mark.springer@ucr edu).

\section{Hypothermia in foraging king penguins}

\section{Y. Handrich*, R. M. Bevan $\dagger$, J.-B. Charrassin ${ }^{\star}$, P. J. Butler $\dagger$, K. Pütz $\ddagger$, A. J. Woakes $\dagger$, J. Lage ${ }^{\star} \&$ Y. Le Maho*}

* Centre d'Ecologie et Physiologie Energétiques, Centre National de la Recherche Scientifique, 23 rue Becquerel, 67087 Strasbourg cedex 2, France

$\dagger$ School of Biological Sciences, University of Birmingham, Edgbaston, Birmingham B15 2TT, UK

$\ddagger$ Abteilung Meereszoologie, Institut für Meereskunde, Düsternbrooker Weg 20, D-24105 Kiel, Germany

The ability to dive for long periods increases with body size ${ }^{1}$, but relative to the best human divers, marine birds and mammals of similar or even smaller size are outstanding performers. Most trained human divers can reach a little over $100 \mathrm{~m}$ in a singlebreath dive lasting for $4 \mathrm{~min}$ (ref. 2), but king and emperor penguins (weighing about 12 and $30 \mathrm{~kg}$, respectively) can dive to depths of 304 and $534 \mathrm{~m}$ for as long as 7.5 and $\mathbf{1 5 . 8} \mathrm{min}$, respectively $^{3-5}$. On the basis of their assumed metabolic rates, up to half of the dive durations were believed to exceed the aerobic dive limit, which is the time of submergence before all the oxygen stored in the body has been used $\mathrm{up}^{4,6,7}$. But in penguins and many diving mammals ${ }^{7,8}$, the short surface intervals between dives are not consistent with the recovery times associated with a switch to anaerobic metabolism ${ }^{4}$. We show here that the abdominal temperature of king penguins may fall to as low as $11^{\circ} \mathrm{C}$ during sustained deep diving. As these temperatures may be 10 to $20^{\circ} \mathrm{C}$ below stomach temperature, cold ingested food cannot be the only cause of abdominal cooling. Thus, the slower metabolism of cooler tissues resulting from physiological adjustments associated with diving per se, could at least partly explain why penguins and possibly marine mammals can dive for such long durations.

King penguins are pelagic predators. To obtain food for their chicks, the parents forage at sea up to the subantarctic or polar frontal zones, $300-1,000 \mathrm{~km}$ away from their breeding colony ${ }^{9,10}$. They essentially rely on myctophid fish, of which most are captured in daytime at $150-300 \mathrm{~m}$ depths ${ }^{11}$. As sea temperatures there are $4{ }^{\circ} \mathrm{C}$ or lower, their stomachs are cooled by ingested prey ${ }^{12,13}$. In freely foraging king penguins, which normally have a body temperature of $38^{\circ} \mathrm{C}$ on land, stomach temperatures as low as $19^{\circ} \mathrm{C}$ have been reported ${ }^{11,14}$. There is a $2-4^{\circ} \mathrm{C}$ fall in body temperature during free diving activity in seals ${ }^{15,16}$ and birds ${ }^{17-19}$ and it has been suggested that a slight reduction in body temperature during diving might enhance aerobic diving time $e^{6,15,17,18}$. The cold food that antarctic animals eat could contribute to this hypothermia ${ }^{14,20-22}$, or the aerobic dive limit (ADL) of penguins might be prolonged by a process of temperature-induced metabolic suppression that is independent of stomach cooling.

To investigate these possibilities, the separate influences of feeding and diving on the abdominal temperatures of foraging animals have to be determined. It is important to obtain simultaneous measurements of the temperatures inside and outside the stomach while the animals are freely diving, so that the extent of the temperature changes in relation to diving and feeding activity during the course of a foraging trip can be found. We therefore implanted three data loggers into each of 12 free-ranging king penguins (see Methods). The data loggers (Fig. 1) measured the temperature of each bird at the top $\left(T_{\text {abtop }}\right)$ and bottom $\left(T_{\text {abbot }}\right)$ of the abdomen, as well as inside the stomach $\left(T_{\text {stom }}\right)$. Hydrostatic pressure was also recorded to monitor the diving behaviour. Both the upper-abdominal and stomach loggers measured the full range of temperatures; the lower-abdominal device recorded temperatures 
only below $22.7^{\circ} \mathrm{C}$ (see Methods and Fig. 2). Before the birds went to sea, upper-abdominal and stomach temperatures did not differ significantly, remaining at the mean value ( \pm s.d.) of $37.5 \pm 0.4{ }^{\circ} \mathrm{C}$ ( $n=8$ birds). Once the birds were at sea, the stomach temperature was significantly higher between diving bouts than when the birds were ashore $\left(38.3 \pm 0.4^{\circ} \mathrm{C} ; n=8\right)$, and systematically higher $\left(0.5 \pm 0.03{ }^{\circ} \mathrm{C} ; n=7, P<0.05\right)$ than the upper-abdomen temperature. In contrast, both upper-abdominal and stomach temperatures fell during foraging dives. The lowest temperature recorded during a bout of deep diving ( $n=52$ for dives deeper than $50 \mathrm{~m})$ ranged from $18.2-37.0^{\circ} \mathrm{C}$ in the stomach and $25.8-37.1^{\circ} \mathrm{C}$ in the upper abdomen ( $n=7$ birds). At any given time, the difference between these two temperatures could be as much as $12^{\circ} \mathrm{C}$. Surprisingly, this difference could be either positive or negative (Fig. 3A). Furthermore, $T_{\text {abbot }}$ was also recorded (that is, it fell below $22.7^{\circ} \mathrm{C}$ ) during prolonged ( $>3 \mathrm{~h}$ ) deep diving (Fig. 2). From ten data sets available, these very low temperatures occurred during $11 \%$ of the time of the overall foraging trip in 7 of the 10 penguins, with $83 \%$ of the total duration of these events being during the last two days of foraging. When recorded, temperature in the lower abdomen was always lower than the other two temperatures, the difference ranging between 2.9 and $20.1{ }^{\circ} \mathrm{C}$. It was at least $2{ }^{\circ} \mathrm{C}$ below stomach temperature. Thus, whereas most previous studies have attributed the decreases in either stomach ${ }^{14,20}$ or abdominal ${ }^{21,22}$ temperatures to the ingestion of cold prey, our results show that the lower abdomen

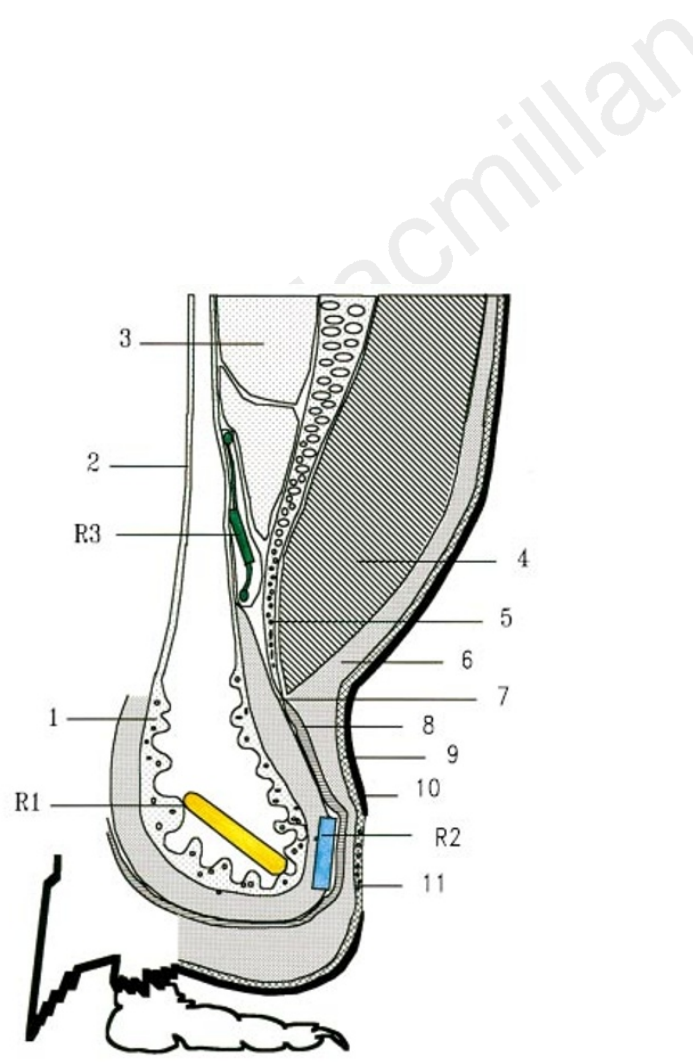

Figure 1 Sagittal view of the abdominal region of a king penguin showing the location of three recorders: $\mathrm{R} 1$, time/temperature recorder located in the stomach; R2, time/temperature/depth recorder implanted in the abdominal fat of the lower abdomen, with an external thermistor placed against the stomach wall; R3, time/ temperature/heart rate recorder implanted under the sternum and against the stomach wall in the upper abdomen. Parts of the penguin's body indicated are: (1) muscular wall of the gizzard; (2) thin wall of the proventriculus; (3) liver lobes; (4) pectoral muscles; (5) sternum; (6) subcutaneous adipose layer; (7) abdominal and visceral fat deposits; (8) external and internal oblique muscles; (9) skin; (10) feathers; (11) well perfused brood patch. is cooled not just by the contents of the stomach but also by other mechanisms (Fig. 3A).

The stomach of the king penguin is divided into two distinct regions, each with a different morphology and thermal insulation (Fig. 1). The lower part, the gizzard, is muscular, well perfused, and well insulated from the abdominal cavity by a thick $(1-2 \mathrm{~cm})$ layer of abdominal fat. In contrast, the upper part, the proventriculus, has a thin wall and is in direct contact with the upper abdominal cavity. At the start of a foraging trip, the gizzard is empty, so any ingestion is easily detected ${ }^{13}$; it can be assumed that the stomach temperature at this time is that of the whole stomach and that there is no substantial temperature gradient within the stomach (Fig. 3B). The temperature in the upper abdomen then decreases by $\sim 1{ }^{\circ} \mathrm{C}$ during the first bout of shallow diving, although there is no evidence of any ingestion (event a in Fig. 3B).

A similarly slight temperature decrease has been reported in the dorsal aortic blood of a freely diving Weddell seal ${ }^{15}$ (Leptonychotes weddellii), which was explained by a reflex decrease in the perfusion of peripheral and/or inactive muscle tissues that caused a reduction in metabolic rate ${ }^{15}$. This idea is supported by data from prolonged deep-diving bouts performed by king penguins. At this stage, a change in stomach temperature was observed for all diving events. This phenomenon has been previously described ${ }^{13}$ and was attributed to the movement of the stomach recorder through different strata of food at different temperatures. However, the temperatures

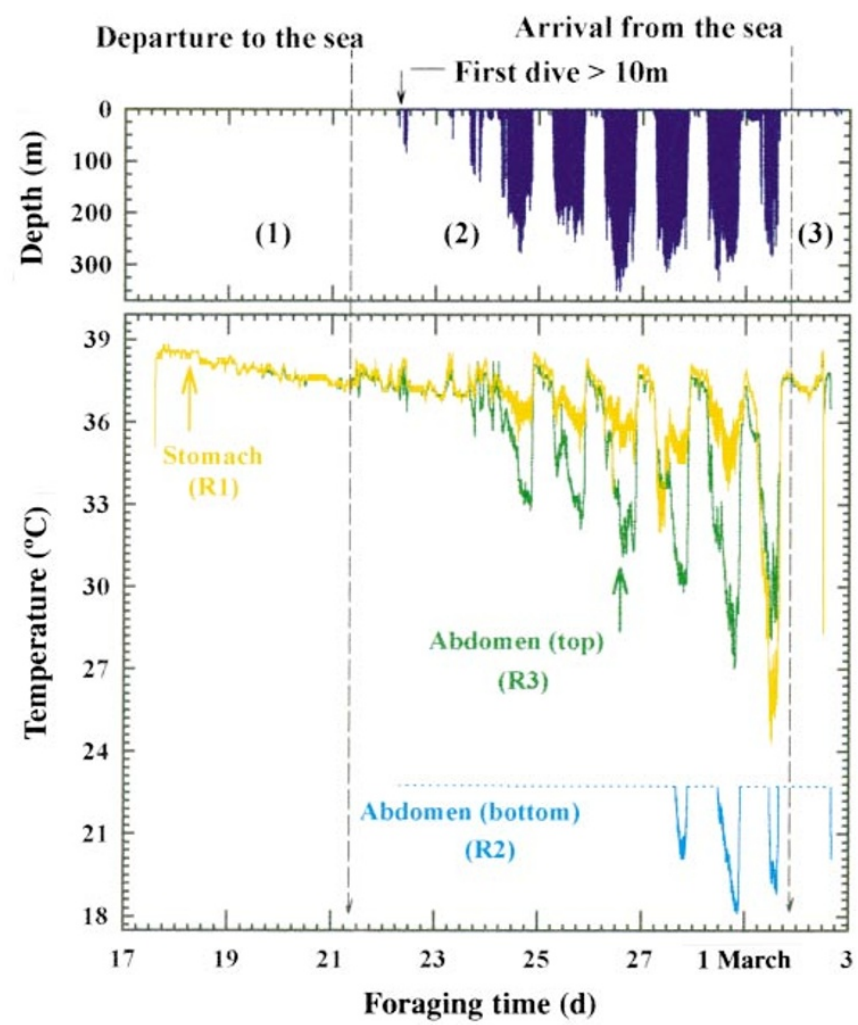

Figure 2 Typical data obtained from a single bird corresponding to: (1) the end of the brooding shift (range, $5-10 \mathrm{~d}$; mean \pm s.d.: $7.3 \pm 1.9, n=12$ ); (2) the foraging trip (range 5.1-10.2 d; mean, $7.5 \pm 1.6$ ); (3) the beginning of the following brooding shift (less than $36 \mathrm{~h}$ ). The typically gradual decrease in stomach temperature $\left(T_{\text {stom }}\right)$ is shown over the $2-5 d$ following implantation, as well as the further periodic decreases in both $T_{\text {stom }}$ and upper-abdominal temperature ( $\left.T_{\text {abtop }}\right)$ which were synchronized with diving bouts. In the example shown here, the lowerabdominal temperature $\left(T_{\text {abbot }}\right)$ fell below $22.7^{\circ} \mathrm{C}$ (the upper limit of the range of $\mathrm{R} 2$ ) in the three last diving bouts, reaching values as low as $18.1^{\circ} \mathrm{C}$. 
A

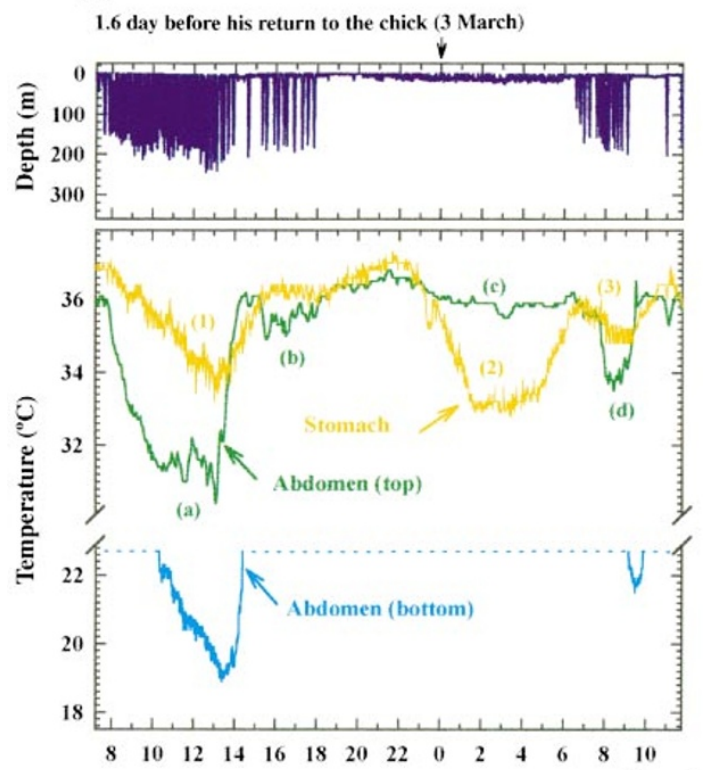

B

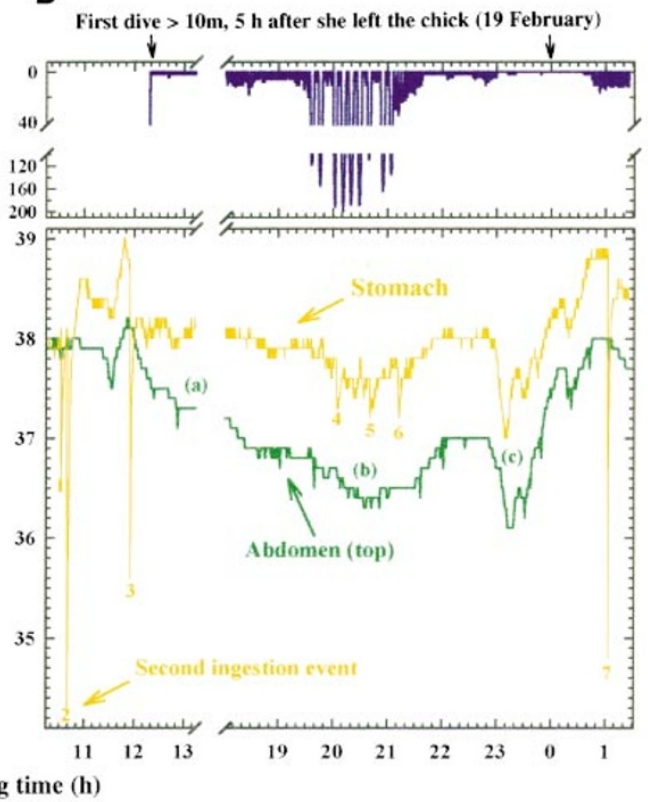

Figure $3 \mathbf{A}$, Representative changes of the three recorded temperatures during different diving activity two days before the end of the foraging trip (bird $\mathrm{N}$ departed on 21 February at 08:02 $\mathrm{h}$ for $10.5 \mathrm{~d}$ of foraging), showing the temporal changes in temperature that occur inside the abdominal cavity. At any given time, temperatures could differ by more than $15^{\circ} \mathrm{C}$. There is a relationship between the reduction in $T_{\text {abtop }}$ and diving behaviour, with slight decreases during periods of shallow diving (c) and larger decreases during deep diving bouts (a, b, d). Although $T_{\text {abtop }}$ may be several degrees lower than $T_{\text {stom }}$ ( 1 is for $T_{\text {stom }}$, a is for $T_{\text {abtop }}$ ) the source of cooling could still be the ingested food because large thermal differences exist in the stomach (see text). Note that, during the resting phase preceding shallow dives, $T_{\text {stom }}$ is still higher than $T_{\text {abtop }}$, which might indicate local heat production during digestion. When temperature data are available for the bottom part of the abdomen (when $T_{\text {abbot }}$ is below $22.7^{\circ} \mathrm{C}$ ) as shown here in two

outside the stomach show similar changes (Fig. 4) and may instead be attributed to reflex adjustments in blood perfusion that are associated with diving per $s e^{23,24}$.

The cooling of less well perfused tissues during descent and the redistribution of blood of different temperatures during ascent ${ }^{23}$ would explain these observations. This means that the monitoring of stomach temperature in marine birds, which has proved useful for detecting prey ingestion events ${ }^{12,13}$, should be re-evaluated in terms of diving hypothermia for calculating the mass of prey ingested by diving species.

As the diving bouts continue, the stomach temperature recorder (located in the gizzard ${ }^{13}$ ) is progressively surrounded by more food, and the sensor becomes unable to detect single ingestion events ${ }^{13}$. When sufficient food has been ingested to fill the proventriculus, a thermal gradient may develop between this cooled compartment and the warmed gizzard ${ }^{25}$. At this stage, the upper abdomen close to the proventriculus was often at a lower temperature than the stomach and this could, at least partly, be attributed to cooling from the proventriculus (event a in Fig. 3A). Ingested food could then contribute to the cooling of the core temperature close to the liver, while the digestive (thermogenic) process continues in the lower gizzard. As this lower part of the stomach is well insulated, the temperature here can be $20^{\circ} \mathrm{C}$ higher than that in the lower abdomen, even though the sensors are only $5 \mathrm{~cm}$ apart. Towards the end of the foraging trips, however, the temperature in the stomach may progressively decrease and become less than that in the lower diving bouts, these events roughly parallel $T_{\text {abtop }}$, with a slight delay, even during the rewarming phase. $\mathbf{B}$, Representative changes in body temperature of a king penguin at sea $5 \mathrm{~h}$ after leaving the chick (bird $\mathrm{K}$ departed on 18 February at $06: 49 \mathrm{~h}$ for $8.0 \mathrm{~d}$ of foraging). At this stage, the stomach is empty and any ingestion of food or water is detected by a typical precipitous fall in $T_{\text {stom }}$ (ingestion events 1 to 7 ; ref. 13). Although there was no ingestion during the $8 \mathrm{~h}$ preceding the first deep-diving bout, $T_{\text {abtop }}$ progressively decreased by more than $1^{\circ} \mathrm{C}$, suggesting that this decline is due to diving per se. The further decrease of $T_{\text {abtop }}$ during a deep diving bout (event b) could be partly due to ingestion (events 4-6). However, the transient drop in both $T_{\text {stom }}$ and $T_{\text {abtop }}$ preceding the rewarming phase (event c), which routinely occurs during a surface phase, argues for a mechanism independent of feeding.

abdomen (Fig. 2, event 2 and 3A). This could result from a slowing down in the processes of digestion and assimilation by the foraging penguin, and from the storage of cold food for the chick.

The cause of the decline in body temperature in freely diving endotherms has been debated for over fifty years, 15,23,26: it may simply be the result of an increase in blood flow to the periphery which causes increased heat loss ${ }^{1,26}$, or there may be a local metabolic depression as a result of reduced blood perfusion ${ }^{15,23}$. These explanations may not be mutually exclusive, at least for breeding king penguins at the beginning of a diving bout. Our results are consistent with the possibility that the king penguin is engaged in an active process of temperature reduction, with the well vascularized brood patch and flippers being effective surfaces for heat loss (Fig. 1). When a diving bout ends and the deep regions of the body gradually rewarm, blood from the active pectoral muscles may be redistributed preferentially to the deeper tissues in order to reduce heat loss from the periphery and to rewarm the core ${ }^{23}$. The question is, would the energy savings from such a regional hypothermia be of overall benefit, considering the cost of rewarming the body? The fact that rewarming occurs while the penguins continue to dive (Figs 2,4) suggests that the 'waste' heat of exercise $^{27}$, rather than shivering thermogenesis, may be used for rewarming. Foraging birds must also travel between prey patches as well as back to the breeding site. 'Waste' heat is therefore readily available during foraging activity and rewarming could occur at little or no extra cost to the birds. 


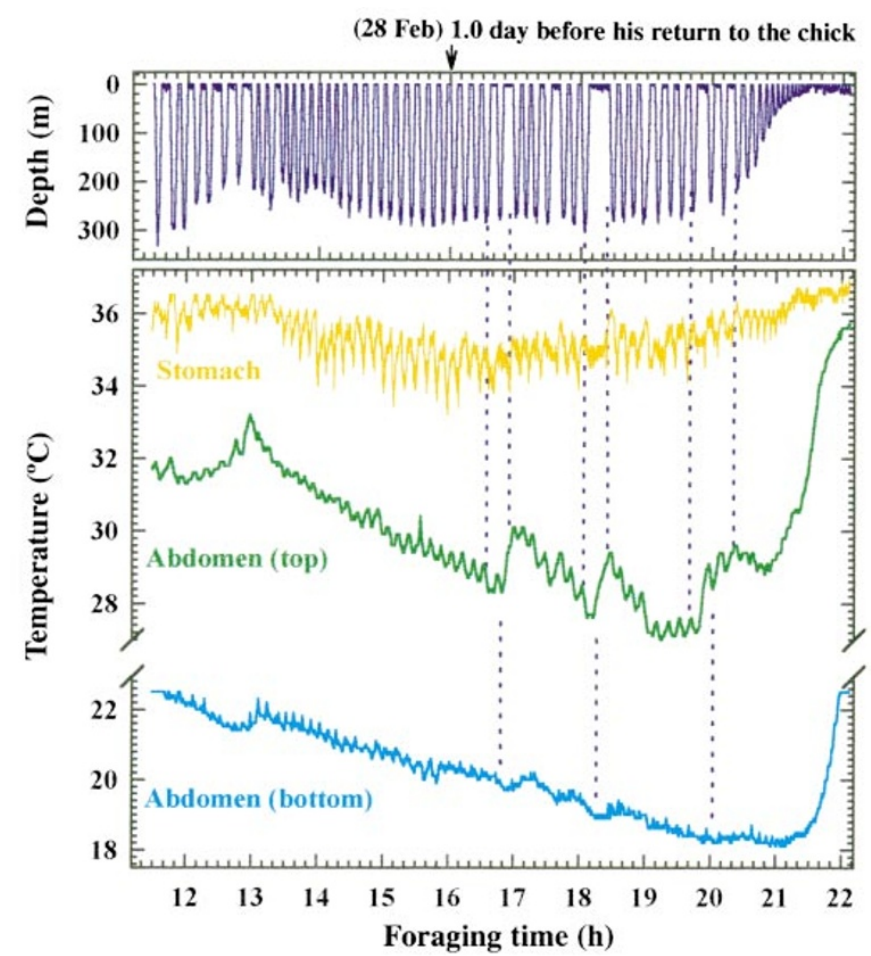

Figure 4 Short-term variations of the three abdominal temperatures near the end of a deep-diving bout and $1 \mathrm{~d}$ before the end of the foraging trip (bird $\mathrm{O}$ returns to the chick on 01 March at 16:08 h after $8.2 \mathrm{~d}$ at sea). There are systematic oscillations of the three temperatures which are clearly associated with individual dives. The synchronization of the three temperatures with diving is not precise, which could be due to physical and electronic delays (sampling interval). Long interdive intervals indicate a tendency for temperatures (particularly $T_{\text {abtop }}$ ) to fall during a dive and to increase during the time spent at the surface. In all cases, the progressive decrease in temperature is probably due to the fact that the post-dive interval is not long enough to allow for a full recovery. These oscillations and progressive decreases may be due to a diving-induced redistribution of blood at different temperatures from different regions of the body.

Our results show that during deep dives, temperatures in certain body regions of freely foraging penguins can decrease much more dramatically $\left(>10^{\circ} \mathrm{C}\right)$ than in the stomach, which is cooled predominantly by the ingestion of cold prey. These temperature decreases, which would lead to a metabolic depression, might help explain the extraordinary diving performance of king penguins and other marine endotherms. The extent of the metabolic depression caused by the lowered temperatures in diving king penguins might confer upon them a significant overall energetic benefit during their foraging trip, which would be a particular advantage at the time breeding parents need to minimize their own energy expenditure while accumulating food in the stomach for their chicks. This energy saving would also be analogous to that which results from torpid periods in hibernators, despite the cost of arousal $^{28,29}$. Finally, although they are much poorer at diving that penguins, the best human divers rely on voluntary control of automatic processes by using techniques such as yoga ${ }^{2}$; these may induce hypometabolism ${ }^{30}$, which, according to our results, is a key process for tolerating an extended breath-hold.

\section{Methods}

Twelve birds (males and females) were equipped two days after the start of their first brooding shift. All chicks were less than $12 \mathrm{~d}$ old. The stomach recorder (R1 in Fig. 1) was swallowed before implantation of the lower- and upper-abdominal temperature recorders. R2 and R3, respectively, were implanted under halothane anaesthesia and sutured in place. For R1: dimensions $(d), 105 \mathrm{~mm} \times 16 \mathrm{~mm}$ diameter ${ }^{13}$; temperature range $(R), 16$ to $41{ }^{\circ} \mathrm{C}$; sampling interval (SI), $16 \mathrm{~s}$. For R2: $d=64 \mathrm{~mm} \times 38 \mathrm{~mm} \times 15 \mathrm{~mm}$ (Wildlife Computer, Inc.); $R,-2.5$ to $22.7^{\circ} \mathrm{C}$; SI, $30 \mathrm{~s}$; depth range, $0-500 \mathrm{~m}$; SI, 3 s. For R3: $d=55 \mathrm{~mm} \times 24 \mathrm{~mm} \times 6 \mathrm{~mm} ; R, 12-41^{\circ} \mathrm{C}$; SI, 60 s. Sampling of stomach temperature $\left(T_{\text {stom }}\right)$ started immediately; upper abdominal temperature $\left(T_{\text {abtop }}\right)$ and hydrostatic pressure sampling started after the first foraging dive that exceeded $10 \mathrm{~m}$. Pressure was recorded from 11 birds. Bottom abdominal temperature $\left(T_{\text {abbot }}\right)$ was from 10 birds; $T_{\text {abtop }}$ was from 8 birds; and $T_{\text {stom }}$ was from 8 birds. Data from all four channels were recorded simultaneously in 7 birds. The 12 birds were recaptured 1-2 days after returning to their chicks. Only one failed in brooding after removal of the three recorders. R2 and R3 were removed surgically and R1 by stomach flushing. All thermistors were simultaneously calibrated $\left( \pm 0.2^{\circ} \mathrm{C}\right)$ after the experiment.

Received 11 December 1996; accepted 18 April 1997.

1. Kooyman, G. L. Diverse Divers (ed. Farner, D. S.) 1-200 (Springer, Berlin, 1989)

2. Corriol, J. H. La Plongée en Apnée. Physiologie et Médecine 2nd edn (Masson, Paris, 1996).

3. Kooyman, G. L. et al. Diving behavior and energetics during foraging cycles in king penguins. Ecol. Monogr. 62, 143-163 (1992).

4. Kooyman, G. L. \& Kooyman, T. G. Diving behavior of emperor penguins nurturing chicks at Coulman island, Antarctica. Condor 97, 536-549 (1995).

5. Ancel, A. et al. Foraging behaviour of emperor penguins as a resource detector in winter and summer. Nature 360, 336-338 (1992).

6. Culik, B. M. et al. Diving energetics in king penguins (Aptenodytes patagonicus). J. Exp. Biol. 199, 973983 (1996).

7. Kooyman, G. L. et al. Heart rates and swim speeds of emperor penguins diving under sea ice. J. Exp. Biol. 165, 161-180 (1992).

8. Boyd, I. L. \& Croxall, J. P. Dive durations in pinnipeds and seabirds. Can. J. Zool. 74, 1696-1705 (1996).

9. Guinet, C. et al. Foraging behaviour of satellite-tracked king penguins in relation to the sea surface temperature obtained by satellite telemetry at Crozet Archipelago during the austral summer: a three year study. Mar. Ecol. Prog. Ser. (in the press).

10. Bost, C. A. et al. Foraging habitat and food intake of satellite-tracked king penguins during the austral summer at Crozet Archipelago. Mar. Ecol. Prog. Ser. (in the press).

11. Pütz, K. \& Bost, C.-A. Feeding behavior of free-ranging king penguins (Aptenodytes patagonicus). Ecology 75, 489-497 (1994).

12. Wilson, R. P. \& Culik, B. M. The cost of a hot meal: facultative specific dynamic action may ensure temperature homeostatis in post-ingestive endotherms. Comp. Biochem. Physiol. 100A, 151-154 (1991).

13. Wilson, R. P. et al. Reliability of stomach temperature changes in determining feeding characteristics of seabirds. J. Exp. Biol. 198, 1115-1135 (1995).

14. Pütz, K. Aspects of the feeding ecology of emperor penguins (Aptenodytes forsteri) and king penguins (Aptenodytes patagonicus). Rep. Polar Res. 136, 1-139 (1994).

15. Hill, D. R. et al. Heart rate and body temperature during free diving of Weddell seals. Am. J. Physiol. 253, R344-R351 (1987)

16. Ponganis, P. J., Kooyman, G. L., Castellini, M. A., Ponganis, E. P. \& Ponganis, K. V. Muscle temperature and swim velocity profiles during diving in a Weddell seal, Leptenychotes weddellii. J. Exp. Biol. 183, 341-348 (1993).

17. Culik, B. M. et al. Core temperature variability in diving king penguins (Aptenodytes patagonicus): a preliminary analysis. Polar Biol. 16, 371-378 (1996).

18. Butler, P. J., Bevan, R. M., Woakes, A. J., Croxall, J. P. \& Boyd, I. L. The use of data loggers to determine the energetics and physiology of aquatic birds and mammals. Braz. J. Med. Biol. Res. 28, 1307-1317 (1995).

19. Bevan, R. M. et al. Heart rate and abdominal temperatures of free-ranging South Georgian shags, Phalacrocorax georgianus. J. Exp. Biol. 200, 661-675 (1997).

20. Wilson, R. P., Cooper, J. \& Plötz, J. Can we determine when marine endotherms feed? J. Exp. Biol. 167, 267-275 (1992).

21. Woakes, A. J., Butler, P. J., Bevan, R. M. \& Boyd, I. L. The metabolic rate of free ranging antarctic animals. Biotelemetry XII 21, 3-223 (1992).

22. Woakes, A. J., Butler, P. J. \& Bevan, R. M. Implantable data logging system for heart rate and body temperature: its application ot the estimation of field metabolic rates in Antarctic predators. Med. Biol. Eng. Comput. 33, 145-151 (1995).

23. Scholander, P. F., Irving, L. \& Grinnel, S. W. On the temperature and metabolism of the seal during diving. J. Cell Comp. Physiol. 19, 67-78 (1942).

24. Bevan, R. M. \& Butler, P. J. Cardiac output and blood flow distribution during swimming and voluntary diving of the tufted duck (Aythya fuligula). J. Exp. Biol. 168, 199-217 (1992).

25. Carey, F. G. A Companion to Animal Physiology (eds Taylor, C. R., Johnsen, K. \& Bolis, L.) 216-235 (Cambridge Univ. Press, 1982).

26. Kooyman, G. L., Wahrenbrock, E. A., Castellini, M. A., Davis, R. W. \& Sinnett, E. E. Aerobic and anaerobic metabolism during voluntary diving in Weddell seals: evidence of preferred pathways from blood chemistry and behavior. J. Comp. Physiol. 138, 335-346 (1980).

27. Ketterson, E. D. \& King, J. R. Metabolic and behavioral responses to fasting in the white-crowned sparrow (Zonotrichia leucophrys gambelli). Physiol. Zool. 50, 115-129 (1977).

28. Heldmaier, G., Steiger, R. \& Ruf, T. Life in the Cold. Ecological, Physiological and Molecular Mechanisms (eds Carey, C., Florant, G. L., Wunder, B. A. \& Horwitz, B.) 545-548 (Westview, Boulder, 1993)

29. Ruf, T. \& Heldmaier, G. The impact of daily torpor on energy requirements in the Djungarian hamster, Phodopus sungorus. Physiol. Zool. 65, 994-1010 (1992).

30. Heller, H. C., Elsner, R. \& Rao, N. Voluntary hypometabolism in an Indian yogi. J. Therm. Biol. 12, 171-173 (1987).

Acknowledgements. We thank G. Froget, Y. Ropert-Coudert, J.-N. Clech and all the 1995 winter team in Crozet for their assistance in the field, and A. Ancel, C.-A. Bost, B. M. Culik and A. Malan for comments on the manuscript. After approval by the ethics committee of the Institut Français pour la Recherche et la Technologie Polaires, this study was supported by a grant for this Institute and by an NERC Small Research grant.

Correspondence and requests for materials should be addressed to Y.H. (e-mail: yves.handrich@ c-strasbourg.fr) 